\title{
The Utilization of Fermented Vegetable Waste on Dry Matter and Organic Matter Digestibility on Local Sheep Feed
}

\author{
P H I Meliala, Hasnudi, S Umar, N Ginting, and AH Daulay \\ Animal Production Program, Faculty of Agriculture, University of Sumatera Utara, \\ Medan 20155 \\ E-mail : jpi@usu.ac.id
}

\begin{abstract}
The study objective was to analyze the value of dry matter and organic matter of fermented vegetable waste on local sheep feed. Research conducted at the Laboratory of Animal Biology and the Laboratory of Nutrition and Feed Science, Animal Science Study Program, Faculty of Agriculture, University of Sumatera Utara, in June - September 2016. The research used local sheep with the average of body weight 13,4 $\pm 1,2 \mathrm{~kg}$. The design experimental used completely randomized design (CRD) with 5 treatments and 4 replications. The treatment were ratio grass with fermented vegetable waste, composed of P0 (100:0), P1 $(75: 25), \mathrm{P} 2(50: 50), \mathrm{P} 3(25: 75)$ and $\mathrm{P} 4(0: 100)$. Variable were measured i.e consumption of dry matter and organic matter and digestibility of dry matter and organic matter.Results of analysis of variance showed that the utilisation of fermented vegetable waste had highly significantly different effect $(\mathrm{P}<0,01)$ on dry matter and organic matter digestibility. Increasing utilization fermented vegetable waste increase dry matter and organic matter digestibility on local sheep feed. The conclusion of this study is the use of fermented vegetable waste can increase the digestibility of dry matter and organic matter on local sheep. Keywords: Waste Vegetable, Fermentation, Digestibility, Local Sheep
\end{abstract}

\section{Introduction}

Sheep breeding is one of the small ruminansia that is maintained by many people, especially in rural areas and generally in the form of local sheep. Local sheep are various types of sheep that have long been cultivated for generations in an area and have adapted well to the local environment. Local sheep have a relatively small size, uniform fur color, small tail and not too long.

Currently, the potential to develop sheep breeding began to open, can be seen from the population of sheep in North Sumatra reached 595,517 head [1]. Constraints that often encountered include low livestock productivity due to low quality feed associated with the availability of forage sources, especially during the dry season, so it is necessary to make alternative replacement alternatives are cheap, easily available and available throughout the season.

This makes breeders look for other alternatives that can be used as forage replacement forage materials. In its development has been a lot of research that tries to find the right alternative to be used as animal feed material whose nutritional content is quite good, as a substitute for forage. As for which has been used as feed ingredients derived from plantation waste, agricultural waste and waste food and beverage industry. Utilization of waste as a substitute feed ingredients, in addition to minimize production costs, can also minimize environmental problems due to the waste.

Vegetable waste is part of unused or disposed vegetables or vegetables and is found in many vegetable markets. The weakness of market vegetables waste is easily decayed, voluminous (bulky) 
and its availability fluctuate so that required feed processing technology to utilize the vegetable waste. Vegetable waste also has some disadvantages as a feed, among others, has a high water content that causes the rapid decay process so that its quality as a fast food decreases. Therefore, vegetable waste that cannot be given directly to livestock need to be processed first to maintain its quality, one of them by fermentation.

Utilization of vegetable waste into raw materials of ruminant feed can be done by processing complete fermentation ration technology. Fermentation is one solution to overcome the negative effects of vegetable waste and at the same time the solution to the lack of feed ruminants. The fermentation process also aims to reduce the crude fiber of a feed material that will aid in the digestion process.

The digestibility of a feed material is very important because it can be used to determine the value or quality of a feed material. The dry matter of a feed material comprises nitrogen compounds, carbohydrates, fats and vitamins. The digestibility of a feed material is influenced by several factors, among others, chemical composition of feed ingredients, ration composition, physical form of ration, feeding rate and factors derived from the livestock itself.

Based on the description, the author intends to conduct research on the utilization of fermented vegetable waste against the digestibility of dry matter and organic ingredients of local sheep feed.

\section{Materials and Research Methods}

\subsection{Place and time of research}

This research was conducted in Laboratory of Animal Biology and Laboratory of Animal Nutrition and Feed Science of Animal Husbandry Program of Faculty of Agriculture, University of Sumatera Utara. This study lasted for three months starting from June 2016 until September 2016.

\subsection{Materials and Research Tools}

The material used is local sheep as much as 20 tail with an initial body weight of $13.4 \mathrm{~kg} \pm 1.2 \mathrm{~kg}$, feed ingredients consisting of grass, fermented vegetable waste and concentrate as reinforcing feed, rodalon as disinfectant and drugs such as worm medicine (Kalbazen) and anti bloat for bloating.

The tool used is a cage of 20 units with a size of $1 \mathrm{mx} 0.5 \mathrm{~m}$, where to feed and drink as many as 20 units, white plastic the size of $5 \mathrm{~kg}$ as a place of fermentation, thermometer to know the temperature inside and outside the cage, the scale of capacity $50 \mathrm{~kg}$ with sensitivity $2 \mathrm{~kg}$ to weigh the weight of sheep, the scales with a capacity of $2 \mathrm{~kg}$ with a sensitivity of 10 grams to weigh the feed, the cage cleaner, the enclosure, the freezer to store the feces during the total collection of feces, the oven to dry the feed material and analyze the feces, chopper machine to chop chop corn, grinder to smooth the feed material and stationery to write data.

\subsection{Research methods}

The research method used was experimentally using a completely randomized design (RAL) consisting of 5 treatments and 4 replications.

\subsection{Observed Variables}

1. Dry matter digestibility (KcBK)

Dry matter digestibility can be measured by calculating by the formula:

$$
\text { Digestibility BK }=\frac{\text { konsumsi BK (gram) }- \text { BK feses (gram) }}{\text { konsumsi BK (gram) }} \times 100 \%
$$

The treatment provided is as follows:

P0: $100 \%$ grass without fermented vegetable waste + Concentrate

P1: $75 \%$ grass and $25 \%$ fermented vegetable waste + Concentrate

P2: 50\% grass and 50\% fermented vegetable waste + Concentrate 
P3: $25 \%$ grass and $75 \%$ fermented vegetable waste + Concentrate

P4: $100 \%$ fermented vegetable waste + Concentrate

The experimental mathematical model used is a complete randomized design (RAL) is:

$\mathrm{Yij}=\mu+\sigma \mathrm{i}+\mathrm{\epsilon ij}$

Information:

$\mathrm{i}=1,2,3$, treatment

$\mathrm{j}=1,2,3$ repeat

Yij $=$ observation value of the ith treatment and the $\mathrm{j}$ th repeat

$\mu=$ common middle value

$\sigma i=$ effect of the ith treatment

$\epsilon \mathrm{ij}=$ the effect of experimental error from the ith treatment on $\mathrm{jth}$ threshold

2. Organic Material Degradation (KcBO)

The digestibility of organic matter can be measured by calculating by the formula:

$$
\text { Digestibility BO }=\frac{\text { BO consumption }(\text { gram })-\text { BO feces }(\text { gram })}{\text { BO consumption }(\text { gram })} \times 100 \%
$$

\section{Results and Discussion}

The results showed a very significant difference $(P<0.01)$ on all parameters of material consumptiondry, organic matter consumption, dry matter digestibility and organic matter digestibility presented in the table below.

Table 1. Parameters : dry matter consumption, organic matter consumption, dry matter digestibility and organic matter digestibility

\begin{tabular}{cllll}
\hline \multirow{2}{*}{ Treatment } & \multicolumn{4}{c}{ Parameter } \\
\cline { 2 - 5 } & $\begin{array}{l}\text { drymatter } \\
\text { consumption } \\
\text { (gram/ekor/hari) }\end{array}$ & $\begin{array}{l}\text { organic matter } \\
\text { consumption } \\
\text { (gram/ekor/hari) }\end{array}$ & $\begin{array}{l}\text { dry matter } \\
\text { digestibility } \\
(\%)\end{array}$ & $\begin{array}{l}\text { organic matter } \\
\text { digestibility } \\
(\%)\end{array}$ \\
\hline P0 & $254,61^{\mathrm{d}}$ & $225,51^{\mathrm{d}}$ & $56,30^{\mathrm{d}}$ & $63,93^{\mathrm{c}}$ \\
P1 & $274,10^{\mathrm{d}}$ & $246,06^{\mathrm{d}}$ & $57,49^{\mathrm{d}}$ & $64,56^{\mathrm{c}}$ \\
P2 & $344,42^{\mathrm{c}}$ & $314,29^{\mathrm{c}}$ & $60,65^{\mathrm{c}}$ & $66,96^{\mathrm{b}}$ \\
P3 & $417,23^{\mathrm{b}}$ & $384,40^{\mathrm{b}}$ & $64,67^{\mathrm{b}}$ & $69,92^{\mathrm{a}}$ \\
P4 & $480,14^{\mathrm{a}}$ & $446,00^{\mathrm{a}}$ & $67,27^{\mathrm{a}}$ & $71,66^{\mathrm{a}}$ \\
\hline
\end{tabular}

Description: Different superscripts in the same column show a very significant different effect $(\mathrm{P}<0.01)$.

\subsection{Dry Matter Consumption}

From the data of dry matter consumption in the above table shows the highest average on treatment P4 (vegetable waste fermentation $100 \%$ + concentrate) that is equal to 480,14 gram / head / day and lowest rate at treatment P0 (grass 100\% + concentrate) that is equal to 254, 61 grams / head / day.

Based on the analysis of the variety of consumption of dry ingredients of feed during the study gave a very significant different effect $(\mathrm{P}<0.01)$. Further Duncan test results showed that the average consumption of dry matter feed between $\mathrm{P} 0, \mathrm{P} 1, \mathrm{P} 2, \mathrm{P} 3$ and $\mathrm{P} 4$ was very significant $(\mathrm{P}<0.01)$. The treatment between $\mathrm{P} 0$ and $\mathrm{P} 1$ gave no significant effect, whereas between P4 and P3, P2, P1 and P0 gave a very different effect.

The very real difference in dry matter consumption is influenced by several factors such as the condition of cattle health, the level of feed digestibility and the quality of the feed resulting in a very real difference in the consumption of dry matter feed. This is in accordance with the statement of Tomaszewska et al. [2] which states that the level of consumption is strongly influenced by the coefficient of digestibility, feed quality, fermentation in the rumen and physiological status of 
livestock. Feed quality is determined by the level of digestibility of feed substances contained in the feed. This is also in accordance with the Parakkasi statement [3] which states that the rate of consumption difference is influenced by several factors such as livestock factors (body weight, age, feed intake rate, feed quality and palatability).

Feed treatment given to sheep resulted in the consumption of dry matter during the study ranged from 254,61 gram / head / day to 480,14 gram / head / day. The dry matter consumption of sheep in this study was lower than the dry matter consumption of sheep in the study of Ekawati et al. [4] that is equal to 678,27 - 811,43 gram / ekor / hari given feed in the form of complete hyacinth silage rituum added starter Lactobacillus plantarum.

The results showed that during sheep study only able to consume dry matter feed for $1.77 \%$ of body weight per day, where the results are lower than the results of research Ekawati et al. [4] that is 3.41 $-4.30 \%$ of body weight per day given feed in the form of complete hyacinth ration complete hyacinth starter Lactobacillus plantarum. The results were also lower than the NRC statement [5] which states that sheep are able to consume dry matter (BK) feed as much as $2.5-4 \%$ of body weight per day, concentrate can be given two percent and the rest is forage or fibrous feed high. It is also supported by Purbowati et al. [6] in JurnalEkawati et al. [4] which states that the range of consumption of dry matter (BK) feed on rams ranges from $3-5.58 \%$.

The low consumption of sheep dry matter during the study was due to sheep's declining health due to diarrheal diseases which affected the decrease of feed consumption. This is in accordance with the statement of Prihatman [7] which states that normal ruminant livestock (not in a state of sickness or being in production), consumes a limited amount of feed according to their need to meet basic life. Then in line with the growth, development conditions and the level of production it produces, feed consumption will increase as well. Highly low intake of feed on ruminant livestock is strongly influenced by external factors (environment) and internal factors (the condition of the livestock itself).

\subsection{Organic Matter Consumption}

From the data of consumption of organic matter in the above table shows the highest average on the treatment of P4 (vegetable waste fermentation $100 \%$ + concentrate) that is equal to 446.00 gram / head / day and the lowest rate in treatment P0 (grass 100\% + concentrate) that is equal to 255, 51 grams / head / day.

Based on the analysis of the variety of consumption of organic matter of feed during the study gave a very significant different effect $(\mathrm{P}<0.01)$. Duncan's further test shows that the average consumption of organic matter feed between P0, P1, P2, P3 and P4 is very significant $(\mathrm{P}<0.01)$. Treatment

Different results are markedly adapted to the results of dry matter consumption. This is due to the consumption of organic material feed in line with the consumption of dry matter feed because the dry material consists of organic materials and ash so that the amount of organic matter consumption is directly proportional to the amount of consumption of dry matter. This is in accordance with the statement of Fathul and Wajizah [8] which states that organic matter is part of the dry matter, so that if the dry matter increases will increase the organic material, and vice versa.

Feed treatment given to sheep resulted in the consumption rate of organic matter of feed during the study ranged from 225,51 gram / head / day to 446,00 gram / head / day. The range of consumption of sheep organic matter in this study was lower than the range of consumption of sheep organic matter in the study of Ekawati et al. [4] that is equal to 610,79 - 704,35 gram / head / day given feed in the form of complete hyacinth silage rituum added starter Lactobacillus plantarum. The consumption of organic matter is closely related to the consumption of the dry matter. The more consumption of dry ingredients, the more the consumption of organic matter [9].

\subsection{Dry matter digestibility}

Dry matter digestibility was measured to determine the amount of feed substances absorbed by the body through analysis of the amount of dry matter, both in rations and in feces. The difference 
between the amount of dry matter consumed and the amount of excretion divided by the amount of dry matter consumed is dry matter digestibility.

From the dry matter digestibility data on the table above shows the highest average on the treatment of P4 (fermented vegetable waste $100 \%$ + concentrate) that is equal to $67.27 \%$ and the lowest average in treatment P0 (grass $100 \%$ + concentrate) that is equal to $56,30 \%$.

Based on the analysis of the variety of food dry matter digestibility during the study gave a very significant different effect $(\mathrm{P}<0.01)$. Further Duncan test results showed that the average dry matter digestibility of $\mathrm{P} 0, \mathrm{P} 1, \mathrm{P} 2, \mathrm{P} 3$ and $\mathrm{P} 4$ was very significant $(\mathrm{P}<0.01)$. The treatment between $\mathrm{P} 0$ and P1 gave no significant effect, whereas between P4 and P3, P2, P1 and P0 gave a very different effect. This is because each livestock has different capabilities in digesting the ration, thus causing different digestibility values. This is in accordance with Sutardi's [10] statement in Basri's Script [11] which states that dry matter digestibility is influenced by feed protein content, because each protein source has different solubility and degradation resistance. Each type of ruminant livestock has rumen microbes with different abilities in degrading the ration, resulting in different digestibility.

The feed treatment given to sheep produced dry matter digestibility level during the study ranged from $56.30 \%$ to $67.27 \%$. The sheep sheep's dry matter ratios in this study were lower than that of sheep dry matter digestibility in the study of Ekawati et al. [4] that is equal to 69,82 - 70,51\% which given feed in the form of complete hyacinth ration complete water hyacinth starter Lactobacillus plantarum. According to Rianto et al. [12] dry matter digestibility value in thin tailed sheep that was given pollard with different level ranged from $58.02 \%$ to $68.28 \%$ influenced by the content of dietary SK and feed consumption.

Consumption with digestion affects one another. If consumption increases then the digestibility of feed will increase, and vice versa. The digestibility of the dry matter feed illustrates how much dry matter the feed can be utilized by sheep. This is consistent with the statement of Tillman et al. [13] which states that the value of feed digestibility reflects the level of nutrient values that can be utilized by the livestock body used for the production of both basic necessities and weight gain. Higher digestibility value of feed means feed treatment that can be utilized livestock higher. The digestibility of the feed is influenced by the feed composition, the amount of feed given, the feed form and the crude fiber content in the feed given to the livestock.

\subsection{Organic Matter Digestibility}

The digestibility of organic materials in the digestive tract of livestock includes the digestibility of feed substances in the form of components of organic materials such as carbohydrates, proteins, fats and vitamins. The difference in the amount of organic matter consumed and the amounts expressed divided by the amount of organic matter consumed is the digestibility of organic matter.

From the data of digestibility of organic matter in the above table shows the highest average on treatment $\mathrm{P} 4$ (fermented vegetable waste $100 \%$ + concentrate) that is equal to $71,66 \%$ and lowest rate at treatment of P0 (grass $100 \%$ + concentrate) that is equal to $63,93 \%$.

Based on the analysis of the diversity of organic food material digestibility during the study gave a very significant different effect $(\mathrm{P}<0.01)$. Further Duncan test results showed that the average digestibility of organic matter feed between $\mathrm{P} 0, \mathrm{P} 1, \mathrm{P} 2, \mathrm{P} 3$ and $\mathrm{P} 4$ was very significant $(\mathrm{P}<0.01)$. The treatment between $\mathrm{P} 0$ and $\mathrm{P} 1$ gave no significant different effect, $\mathrm{P} 3$ and $\mathrm{P} 4$ gave no significant effect whereas between $\mathrm{P} 4$ and $\mathrm{P} 3$ with $\mathrm{P} 2, \mathrm{P} 1$ and $\mathrm{P} 0$ gave a very different effect.

Different results are very significant to the digestibility of organic materials in line with the digestibility of the dry matter because the organic matter is part of the dry matter so that when the dry matter increases it will increase the organic material and vice versa. This is in accordance with the statement of Fathul and Wajizah [8], which states that organic matter is part of the dry matter, so that if the dry matter increases will increase the organic material, and vice versa. Therefore, it will also apply to the value of digestibility, if the dry matter digestibility $(\mathrm{KcBK})$ increases, the organic matter digestibility $(\mathrm{KcBO})$ will also increase. Therefore, the factors that affect the high dry matter digestibility $(\mathrm{KcBK})$ will also affect the low digestibility of organic matter $(\mathrm{KcBO})$ rations 
The feed treatment given to sheep yielded the level of digestibility of organic material during the study ranged from $63.93 \%$ to $71.66 \%$. The range of digestibility of sheep organic matter in this study was lower than that of sheep organic matter digestibility in the study of Ekawati et al. [4] that is equal to $71,45-73,75 \%$ given feed in the form of complete hyacinth ration complete hyacinth starter Lactobacillus plantarum. The yield range of organic lamb ingredients in the study was similar to that of Rianto et al.[12] where the digestibility value of organic material in thin tailed sheep that was given pollard with different level ranged between $60,81 \%$ to $71,13 \%$ influenced by the content of feed and feed consumption.

The digestibility value of organic material ranged from $63.93 \%$ to $71.66 \%$ higher than the dry matter digestibility value which ranged from $56.30 \%$ to $67.27 \%$ caused by the organic material does not contain ash so that the material without ash content is relatively more easy to digest. This is consistent with the statement of Fathul and Wajizah [8] which states that dry ingredients in the feed still contain ash, whereas organic matter does not contain ash, so that the material without ash content is relatively easier to digest. The content of ash slows or inhibits the digestion of dry matter rations.

\section{Conclusions}

Increased use of fermented vegetable waste increases the consumption of dry matter and organic matter as well as the digestibility of dry matter and organic ingredients of local sheep feed. Utilization of waste fermented vegetables up to $100 \%$ level can increase the digestibility of dry materials and organic materials and can be used as alternative feed material for local sheep

\section{References}

[1] Central Statistics Agency of North Sumatra Province. 2013. Agriculture Statistics of North Sumatra. Medan.

[2] Tomaszeweska, M. W., I. M. Mastika., A. Djajanegara., S. Gradiner dan T. R. Wiradarya. 1993. Produksi Kambing dan Domba di Indonesia (Goat and Sheep Production in Indonesia). Universitas Sebelas Maret. Surabaya.

[3] Parakkasi, A. 1995. Ilmu Nutrisi Ruminansia Pedaging (Science of Ruminant Nutrition Broiler). Departemen Ilmu Makanan Ternak, Fakultas Peternakan, IPB. Bogor.

[4] Ekawati, E., A. Muktiani dan Sunarso. 2014. Efisiensi dan kecernaan ransum domba yang diberi silase ransum komplit eceng gondok ditambahkan starter Lactobacillus plantarum (Efficiency and digestibility of sheep ration given complete silage ration of water hyacinth was added starter Lactobacillus plantarum). Agripet Vol. 14, No. 2.

[5] NRC. 1985. Nutrient Requirement of Sheep 7thEd. National Academy Press. Washington D.C.

[6] Purbowati, E., Sutrisno, C.I., Baliarti, E., Budhi, S.P.S., danLestariana, W. 2007. Pengaruh pakan komplit dengan kadar protein danenergi yang berbeda pada penggemukan domba local jantan secara feedlot terhadap konversi pakan (Effect of complete feed with different protein and energy levels on local feed sheep feedlot on feed conversion). Prosiding Seminar Nasional Teknologi PeternakandanVeteriner. Pusat Penelitian dan Pengembangan Peternakan, Badan Penelitian dan Pengembangan Pertanian, Departemen Pertanian, Bogor. Hal: 394-401.

[7] Prihatman, K. 2000. Pakan Ternak. Proyek Pengembangan Ekonomi Masyarakat Pedesaan (Animal feed. Rural Community Economic Development Project). Bappenas. Jakarta. Diaksesdarihttp://www.peternakan.litbang.deptan.go.id.

[8] Fathul, F dan S. Wajizah. 2010. Penambahan mikro mineral $\mathrm{Mn}$ dan $\mathrm{Cu}$ dalam ransum terhadap aktivitas biofermentasi rumen domba secara in vitro (The addition of micro minerals $\mathrm{Mn}$ and $\mathrm{Cu}$ in ration to rumen sheep biofermentation activity in vitro). JITV 15 (1) : 9-15.

[9] Van Soest, P. J. 1994. Nutritional Ecology of the Ruminant. 2nd Ed. Cornell University Press. London 
[10] Sutardi, T. 1979. Ketahanan protein bahan makanan terhadap degradasi mikroba rumen dan manfaatnya bagi peningkatan produktivitas ternak. Prosiding Seminar Penelitian dan Penunjang Peternakan (Food protein resistance to rumen microbial degradation and its benefits for increasing livestock productivity. Proceedings of Research Seminar and Livestock Support). LPP Institut Pertanian Bogor. Bogor.

[11] Basri. 2014. Kecernaan bahan kering dan bah anorganik ransum komplit dengan kandungan protein berbeda pada kambing maric jantan (Dry matter digestibility and organic matter complete ration with different protein content in male maric goats). Skripsi. Fakultas Peternakan. Universitas Hasanuddin. Makassar.

[12] Rianto, E., E. Haryonodan C.M.S. Lestari. 2006. Produktivitas domba ekor tipis jantan yang diberi pollard dengan aras berbeda (Productivity of thin male tail sheep given pollard with different levels). Seminar Nasional Teknologi Peternakan dan Veteriner. 431-439.

[13] Tillman, A. D., H. Hartadi., S. Reksohadiprojo., S. Prawirokusumodan S. Lendosoekodjo. 1998. Ilmu Makanan Ternak Dasar (Basic Animal Food Science). Cetakan Kedua Peternakan. Gajah Mada University Press. Yogyakarta. 